\title{
Management Practices And Technical Efficiency of MASIPAG Rice Farmers in Isabela, Philippines
}

\author{
Jerald M. Velasco
}

\begin{abstract}
The study was conducted to assess the management practices and technical efficiency of the MASIPAG rice farmers in Isabela, Philippines. A total of 64 respondents were interviewed. Data were analyzed with descriptive and inferential statistics using Stochastic Frontier Analysis. The data revealed that $82.81 \%$ of farmers were male and $17.19 \%$ were female, farmers have an average age of 43.94. The average household size were 5.72, majority of the farmers finished high school, average number of years in farming of 23.84, most of the respondents farmers owned their land that they till, average number of training were 1.06 , and farmers have an average income of $P h p$ 47,687.50. The result showed that the average amount of seed applied by the MASIPAG farmers were 55.66 kilograms per hectare. MASIPAG used organic fertilizer. In terms of managing pest in their production, MASIPAG farmers used natural materials like FPJ, FFA, and FAA. SFA indicated that seeds, fertilizer, pre and post-harvest labor and capital were found to be significant indicators of technical efficiency at $1 \%$ level of significance. Technical inefficiency model showed that age, farming system, household size, educational attainment, number of years in farming, type of soil, crop establishment were found to be significant indicators of technical inefficiency for the MASIPAG farmers.
\end{abstract}

Index Terms-Cobb-Douglas Production Function, Stochastic Frontier Analysis, Technical Efficiency

\section{INTRODUCTION}

Cagayan Valley region remains to be the second top rice producers throughout the country [1]. DA Regional Director Lucrecio Alviar reported that the region was able to harvest 2.08 million metric tons of rice, or estimated to 12.85 percent of the total production in the country for the year. Isabela had produced rice of around 1,068,275 metric tons, followed by Cagayan with 724,622 metric tons, Nueva Vizcaya with 218,446 metric tons and Quirino with 73,423 metric tons

Rice has a great economic importance as it serves as a source of income and a major staple food in most of the municipalities in Isabela. However, In the Philippines, importation has remained as one of the most feasible options for the government to meet the growing demand for rice [2]. Some news reported that Philippines is not yet a rice selfsufficient country. DA secretary Proceso Alcala said that the country still needs to import rice as it fell short of achieving the 100 percent rice self-sufficiency rate [3].

In the growing demand for a safe and nutritious food, organic farming is being practiced by some farmers in
Isabela. "Magsasaka at Siyentipiko para sa Pag-unlad ng Agrikultura" (MASIPAG) is a farmer-led network of people's organizations, Non-Government Organizations and scientists following the mission to improve the life quality of resource-poor farmers [4]. This group of farmers has worked towards a sustainable use and management of biodiversity through farmers' control of genetic and biological resources, agricultural production and associated knowledge.

However, organic farms are not as productive as conventional ones [5]. So many other factors have been blamed for the low level of rice production, which include high cost of inputs, low price of "palay", lack of capital, labor problem, lack of postharvest facilities, pest and diseases and irrigation system [6]. In terms of rice crop protection related problems, costly pesticides/weedicide and ineffective fungicide were identified by the farmers and in terms of marketing related problems of rice crop, unsatisfactory price offered of the produce, poor transportation, storage issues and lack of knowledge about market prices were identified by the farmers [7]. Some of the possible reasons were the stress encountered by the farmers face in the local production which is attributed to insufficient financial, calamities, and soil and irrigation/water management [8].

All the factors that influence the technical efficiency and productivity are the economic and social factors, some of which include factors such as farmer age, education and experience, the number of household members and others [9]. This has therefore been observed to lead to the recent effectiveness and the management practices of rice production particularly in the municipality of Tumauini, Isabela.

The main objective of the study was to assess the management practices and technical efficiency of MASIPAG rice farmers in Isabela, Philippines. Specifically, it aimed to; (1) describe the demographic characteristics of the MASIPAG farmers; (2) describe their management practices and; (3) determine and analyze the factors affecting their technical efficiency. 


\section{Materials AND Methods}

The study covered the municipality if Tumauini which constitutes the most numbers of active members of MASIPAG in the province of Isabela. The municipality of Tumauini is located at the northern portion of the province of Isabela. Its land area is 46,730 hectares (115,500 acres) or $5.62 \%$ of the total land area of Isabela. It is bounded on the north by the municipality of Cabagan and 68 kilometers (42 mi) south from Tuguegarao.

A total of 64 respondents were interviewed. They were the active members of MASIPAG organization which were presently located at Bayabo East, Tumauini, Isabela. Data were gathered during the month of August to October 2017 covering their production period in the year 2016 on their dry and wet season. A semi-structured survey and open ended questionnaire was designed as a primary tool in gathering data. Personal interview were employed and Key Informant Person were also tapped for the data gathering. Secondary data were secured from files and reports of concerned agencies, officers and leaders of the organization.

Data were analyzed using descriptive statistics like percentages and averages. Stochastic Frontier Analysis (SFA) with a computer software Front 4.1 version using Cobb-Douglas production function and Maximum Likelihood Estimates (MLE) method was used to assess the productivity and technical efficiency of MASIPAG rice farmers.

\section{Stochastic Frontier Regression}

Stochastic production frontier analysis has been widely used to study technical efficiency in various settings since its introduction by Aigner [10], and Meeusen and van den Broeck [11].

This tool tested the effects of excess inputs and uncontrollable variables to the efficiency of the rice farmers. The effects were stated in a linear form such as:

The assumption was farmers were maximizing output (yield) and minimizing use of inputs. Hence, farms were in the optimum condition of farm operation because they were efficient in the use of inputs. Thus, the equation was expressed as:

$$
\begin{aligned}
& \qquad Y=X_{i} b+e_{i} \\
& \text { where: } \quad Y=\text { yield per hectare } \\
& X_{i}=\text { columns of inputs: } \\
& X_{1} \text { - Quantity of Seeds Used }(\mathrm{kg} / \mathrm{ha}) \\
& \mathrm{X}_{2} \text { - Quantity of Fertilizer Applied }(\mathrm{kg} / \mathrm{ha}) \\
& \mathrm{X}_{3} \text { - Pre and Post-Harvest Labor (man-day/ha) } \\
& \mathrm{X}_{4} \text { - Machine Services (machine hours/ha) } \\
& \mathrm{X}_{5} \text { - Amount of Pesticides (liter/ha) } \\
& \mathrm{X}_{6} \text { - Farm Capital Investment }(\mathrm{Php} / \mathrm{ha})
\end{aligned}
$$

$\mathrm{b}=$ are series of parameters to be tested at $\% 1$ and $5 \%$ level $\mathrm{e}_{\mathrm{i}}=$ the stochastic random error representing the influence of other variables or randomness of human behavior that cannot be totally predicted.

In the frontier, farms failed to optimize because they incurred slack (waste utilization of the farm inputs). Hence, they failed to reach efficiency. Thus, the equation expressed as:

$$
\mathrm{Y}=\mathrm{X}_{\mathrm{i}} \beta+\left(\mathrm{V}_{\mathrm{i}}-\mathrm{U}_{\mathrm{i}}\right) \quad \mathrm{i}=1, \ldots \ldots 6 .
$$

where: $\mathrm{Y}=$ yield per hectare in natural $\log (\mathrm{Ln})$
$\mathrm{X}_{\mathrm{i}}=$ Column of inputs in $\mathrm{Ln}$ are:

$X_{1}$ - Quantity of Seeds Used (kg/ha)

$\mathrm{X}_{2}$ - Quantity of Fertilizer Applied ( $\left.\mathrm{kg} / \mathrm{ha}\right)$

$\mathrm{X}_{3}$ - Pre and Post-Harvest Labor (man-day/ha)

$\mathrm{X}_{4}$ - Machine Services (machine hours/ha)

$\mathrm{X}_{5}$ - Amount of Pesticides (liter/ha)

$\mathrm{X}_{6}$ - Farm Capital Investment (Php/ha) level

$\beta=$ are series of parameters to be tested at $\% 1$ and $5 \%$

$\mathrm{V}_{\mathrm{i}}$ are the random variables which are assumed to be independent and identically distributed truncated normal with zero mean and variance, and independent of the technical inefficiency.

$\mathrm{U}_{\text {it }}$ which are non-negative random variables which are assumed to account for technical inefficiency in the rice farmers' activities and are assumed to be independently distributed as truncations at zero of the distribution.

$$
\mathrm{U}_{\mathrm{it}}=\mathrm{b}_{\mathrm{i}} \mathrm{D}_{\mathrm{it}}, \quad \mathrm{i}=1, \ldots \mathrm{N} \mathrm{t}=1, \ldots ., 2
$$

where:

$D_{\text {it }}$ are the variables which may influence the farming efficiency of Masipag farmers, expressed as:

$$
\begin{aligned}
& D_{0}=\text { Constant } \\
& D_{1} \text { - Age } \\
& D_{2} \text { - Household Size } \\
& D_{3} \text { - Elementary level } \\
& D_{4} \text { - Elementary graduate } \\
& D_{5} \text { - High school level } \\
& D_{6} \text { - High school graduate } \\
& D_{7} \text { - College level } \\
& D_{8}-\text { College Graduate } \\
& D_{9}-\text { Number of years in Farming } \\
& D_{10} \text { - Land Tenancy Status } \\
& D_{11} \text { - No Trainings/ Seminar Attended } \\
& D_{12} \text { - Type of Farm } \\
& D_{13} \text { - Area of Farm } \\
& D_{14}-\text { Topography } \\
& D_{15} \text { - Type of Soil } \\
& D_{16} \text { - Number of times of planting } \\
& D_{17} \text { - Seed Selection } \\
& D_{18} \text { - Seed Germination treatment } \\
& D_{19} \text { - Land Preparation } \\
& D_{20} \text { - Crop Establishment } \\
& D_{21}-\text { Nutrient Management } \\
& D_{22} \text { - Integrated nutrient management } \\
& D_{23} \text { - Pest Management } \\
& D_{24} \text { - Water Management } \\
& D_{25}-\text { Harvesting } \\
& D_{26} \text { - Farming System }
\end{aligned}
$$

$\mathrm{b}_{\mathrm{i}}=$ are parameters to be estimated and tested at $5 \%$ and $1 \%$ level

$\mathrm{Y} / \mathrm{Y}^{*}=$ maximum potential rice yield of Masipag farmers Where:

$\mathrm{Y}^{*}=$ estimated rice yield of farmers (frontier)

$\mathrm{Y}=$ actual rice yield of farmers

$\sigma^{2}=$ sigma squared $>0$, rice production efficiency are not all $100 \%$ efficient

$\gamma=$ gamma $>0$, the deviation from the frontier are due to technical inefficiency 


\section{RESULTS AND DISCUSSION}

\section{A. Demographic Profile of the Respondents}

Table 1 shows the distribution of 64 respondents of MASIPAG in Isabela, Philippines. The data revealed that $82.81 \%$ of farmers were male and $17.19 \%$ were female. Based from the data, male farmers were engaged in farming rather than females. Farmers were getting older and that younger generations were not involve in rice farming as farmers have an average age of 43.94 years. The average household size of the farmers were 6 members. This conveys that most of the family of the respondents composed of the husband and wife having at least three children. In terms of educational attainment, farmers was much enough for the qualification of being a farmer since farmers attained high school graduate. The result shows that, MASIPAG farmers have an average number of years in farming of 23.84 it can be said that the experience of the farmer respondents is sufficient to become an efficient rice farmer as they practice repeatedly their production activities. The data revealed that most of the respondents farmers owned their land that they till. It signifies that respondents lessens their expenses from the payment of renting the land and free to operate the production of their farm. Farmers had one average attended training and average income of $\mathrm{Php}$ $47,687.50$.

TABLE I: DEMOGRAPHIC PROFILE OF MASIPAG FARMERS IN ISABELA, PHILIPPINES.

\begin{tabular}{clcc}
\hline \hline & Particular & Frequency & Particular \\
\hline Sex & & & \\
& Male & 53 & 82.81 \\
& Female & 11 & 17.19 \\
Age & & & \\
& $11-20$ & 6 & 9.38 \\
& $21-30$ & 8 & 12.50 \\
& $31-40$ & 4 & 6.25 \\
& $41-50$ & 18 & 28.13 \\
& $51-60$ & 28 & 43.75
\end{tabular}

Household Size

$2-4$

34.38

$5-7$

22

26

40.63

8-10

16

Mean

6

Educational Attainment

Elementary Level

7

10.94

Elem. Graduate

HS Level

6

9.38

12.50

HS Graduate

19

College Level

10

College Graduate

Number of years in Farming

$\begin{array}{lcc}1-10 & 16 & 25.00 \\ 11-20 & 8 & 12.50 \\ 21-30 & 26 & 40.63 \\ 31-40 & 7 & 10.94 \\ 41-50 & 5 & 7.81\end{array}$

\begin{tabular}{ccc}
\hline \hline Particular & Frequency & Particular \\
\hline M1-60 & 2 & 3.13 \\
Mean & $\mathbf{2 3 . 8 4}$ & \\
Land Tenancy Status & & \\
Land Owner & 39 & 60.94 \\
Tenant & 27 & 42.19 \\
Number of Trainings & & \\
0-1 & 48 & 75.00 \\
$2-3$ & 14 & 21.88 \\
$4-5$ & 2 & 3.13 \\
Mean & $\mathbf{1}$ & \\
Household Income (Php) & & 6.25 \\
1,000-20,000 & 4 & 42.19 \\
21,000-40,000 & 27 & 21.88 \\
41,000-60,000 & 14 & 18.75 \\
61,000-80,000 & 12 & 10.94 \\
$81,000-100,000$ & 7 & \\
Mean & $\mathbf{4 7 , 6 8 7 . 5 0}$ & \\
\hline \hline
\end{tabular}

\section{B. Farm Characteristics}

Table 2 shows the type of farm of the respondents of the study. All of the respondents have a lowland and irrigated farms. It can be said that with the type of farm that the farmers have, they can have a favorable condition in terms of better water supply and management. The average farm area of farmers was 0.63 hectare. This conveys that the average farm size in Tumauini, Isabela was shorter in terms of land areas. Based from the key informant of the study, portion of the land of the farmers were devoted for their red rice. It can be characterized that most of the farms that is being tilled by the respondents of the study were flat and most of the MASIPAG farmers were tilling a clay loam type of soil which was favorable for rice as this is the suitable type of soil for the plant. 
TABLE II: FARM CHARACTERISTICS OF MASIPAG FARMERS IN ISABELA, PHILIPPINES

\begin{tabular}{|c|c|c|}
\hline Particular & Frequency & Particular \\
\hline \multicolumn{3}{|l|}{ Type of Farm } \\
\hline Lowland & 64 & 100 \\
\hline Irrigated & 64 & 100 \\
\hline \multicolumn{3}{|l|}{ Area of Farm(hectare) } \\
\hline 1 and below & 60 & 93.75 \\
\hline 2 to 3 & 4 & 6.25 \\
\hline Mean & 0.63 & \\
\hline \multicolumn{3}{|l|}{ Topography } \\
\hline Undulating & 2 & 3.13 \\
\hline Hilly & 12 & 18.75 \\
\hline Flat & 50 & 78.13 \\
\hline \multicolumn{3}{|l|}{ Type of Soil } \\
\hline Clay & & 10 \\
\hline Loam & 10 & 15.63 \\
\hline Clay Loam & 44 & 68.75 \\
\hline
\end{tabular}

\section{Production Practices}

Table 3 presents the production practices of MASIPAG farmers in Isabela. Based from the production practices of the farmers, majority of the MASIPAG farmers adopted mono-cropping. They were planting rice at least twice a year. In preparing the land before planting, most of them uses a combination of machine and animals. Most $(56.25 \%)$ of the respondents used inbred rice seeds. These are $\mathrm{M}$ (masipag series varieties). Varieties were given by the organization, this is distributed and propagated by the members of the organization. The average amount of seed being used by the farmers were 55.66 kilograms per hectare. The amount of seeds used in production varies depends on the season. All of the respondents were using the "Dapog" system in preparing seedlings. Most of MASIPAG farmers preferred to use "Waray" (random planting) method in establishing their crop. MASIPAG farmers do not make their own organic fertilizers in fact they were buying commercially made organic fertilizers. Many of the farmers were using laboratory soil analysis. In terms of managing pest in their production, farmers uses natural materials in their operation like (FPJ) Fermented Plant Juice, (FAA) Fish Amino Acids, and (FFJ) Fermented Fruit Juice. Source of water comes from the National Irrigation Administration (NIA) and most of them used combined harvester and thresher during harvest.
TABLE III: PRODUCTION PRACTICES OF MASIPAG FARMERS IN ISABELA, PHILIPPINES.

\begin{tabular}{lcc}
\hline \multicolumn{1}{c}{ Particular } & Frequency & Particular \\
\hline Farming System & & \\
$\quad$ Crop Rotation & 4 & 6.25 \\
$\quad$ Intercropping & 24 & 37.5 \\
$\quad$ Mono-cropping & 36 & 56.25 \\
Number of times of planting in a year & \\
$\quad$ Twice & 64 & 100 \\
Land Preparation & & \\
$\quad$ Use of Machine & 3 & 4.69 \\
$\quad$ Use of Animal & 2 & 3.13 \\
$\quad$ Combination & 59 & 92.9 \\
Seed Selection & & \\
$\quad$ Inbreed & 64 & 100 \\
Variety of seeds & & \\
Red Rice(M32, M60) & 64 & 100 \\
Amount of Seeds(kgs/has) & & \\
$\quad$ 41 - 50 & 25 & 39.06 \\
$\quad$ 51 - 60 & 24 & 37.5 \\
$\quad$ 61 - 70 & 4 & 6.25 \\
$\quad$ 71 - 90 & 11 & 17.19 \\
$\quad$ Mean & 55.66 & \\
Seed Germination treatment & & \\
$\quad$ "Dapog" System & 64 & 100 \\
Crop Establishment & & \\
Straight-line method & 8 & 12.50 \\
Broadcast Method \\
"Waray"
\end{tabular}

D. Financial Management

On financial management of the farmers, most of the MASIPAG farmers used notebook and financial statements were prepared in simplest form (Table 4). Almost half of the respondents do not prepare a report. Most of the capital investment in the farm were the cheaper items. The average amount being borrowed by the farmers were Php 29, 367.1936 and usually borrowed from traders. Interest rate 
with an average rate of $7.18 \%$ are paid every after cropping season. Farm inputs that was bought by the farmers were seeds, fertilizers, payment for the machine rent and labor for the pre and post-harvest activities in the farm.

III. FinANCiAl MANAgEMENT OF MASIPAG FARMERS.

\begin{tabular}{|c|c|c|}
\hline Particular & Frequency & Particular \\
\hline \multicolumn{3}{|c|}{ Mode of Recording Transactions } \\
\hline Note Book & 27 & 42.19 \\
\hline Calendar & 19 & 29.69 \\
\hline None & 18 & 28.13 \\
\hline \multicolumn{3}{|l|}{ Financial Statement } \\
\hline Income Statement & 31 & 48.44 \\
\hline None & 33 & 51.57 \\
\hline \multicolumn{3}{|l|}{ Capital Investment } \\
\hline Carabao & 38 & 59.38 \\
\hline Harrow & 31 & 48.44 \\
\hline Hand Tractor & 23 & 35.94 \\
\hline Rotavator & 2 & 3.13 \\
\hline Thresher & 2 & 3.13 \\
\hline $\begin{array}{r}\text { Knapsack Sprayer } \\
\text { Combined }\end{array}$ & 29 & 45.31 \\
\hline Harvester \& Thresher & 2 & 3.13 \\
\hline Truck & & 5 \\
\hline Tricycle & 11 & 17.19 \\
\hline \multicolumn{3}{|l|}{ Source of Capital } \\
\hline Own & 15 & 23.44 \\
\hline Bank & 9 & 14.06 \\
\hline Trader & 40 & 62.50 \\
\hline \multicolumn{3}{|l|}{ Amount Borrowed } \\
\hline $10,000-50,000$ & & 40 \\
\hline $51,000,-100,000$ & 9 & 14.0625 \\
\hline Mean & $29,367.19$ & \\
\hline \multicolumn{3}{|l|}{ Interest per annum } \\
\hline $1-10$ & 30 & 46.88 \\
\hline $11-20$ & 19 & 29.69 \\
\hline Mean & 7.18 & \\
\hline \multicolumn{3}{|l|}{ Payment terms } \\
\hline \multicolumn{3}{|l|}{ Monthly } \\
\hline Amortization & 2 & 3.13 \\
\hline Every cropping & 47 & 73.44 \\
\hline \multicolumn{3}{|l|}{$\begin{array}{l}\text { No. of Years availing } \\
\text { credit }\end{array}$} \\
\hline $1-2$ & 13 & 20.31 \\
\hline $3-4$ & 4 & 6.25 \\
\hline $5-6$ & 32 & 50 \\
\hline $\begin{array}{l}\text { Mean } \\
\text { Credit Utilization }\end{array}$ & 3.27 & \\
\hline Farm inputs & & 49 \\
\hline
\end{tabular}

\section{E. Marketing Practices}

Table 5 shows the marketing practices of MASIPAG farmers. On their marketing practices, MASIPAG farmers can sell their products at a higher prices because of the direct selling to consumers and the value adding activity to the product by milling it and selling it in the form of unpolished rice. MASIPAG chose to sell their produce on a cash basis. Farmers were using their tricycles for delivering their products to buyers which were usually ordered by the government employees.

IV. MARKeting Practices of MASIPAG FARMERS.

\begin{tabular}{lcc}
\hline \multicolumn{1}{c}{ Particular } & Frequency & Particular \\
\hline Buyers of Produce & 59 & \\
Gov't Employee & 2 & 92.19 \\
Friends & 3 & 3.13 \\
$\quad$ Consumption & & 4.69 \\
Methods of Selling & 54 & \\
$\quad$ Cash basis & 7 & 84.38 \\
Credit & 64 & 10.94 \\
Sold directly to buyers & & 100 \\
Mode of Transportation & 59 & 92.19 \\
Tricycle & 2 & 3.13 \\
Bus & 2 & 3.13 \\
Car
\end{tabular}

\section{F. Cost and Return Analysis}

In table 6 it can be seen that MASIPAG farmers were able to produced 3, 096.82 kilograms of rice during dry season and $2,477.46$ on the wet season. Farmers have a total sales of P158, 557.20 during dry season and P126, 845.76 during wet season. MASIPAG farmers have a higher sales due to the practice of direct selling at P80.00/ $\mathrm{kg}$ selling price and adds value from milling and drying their produce. Farmers have a total cost of P42, 958.72 during dry season and P51, 161.00 during wet season. It can be observed that farmers have a higher cost during dry season but cost in farm labor was higher during wet season as can be observed in the table. The decrease in the amount of seeds was due to change of the planting method. During dry season, they used direct seeding which requires higher volume of seed and lower volume for transplanting during wet season. Generally, MASIPAG have lower cost in terms of fertilizer because of organic fertilizer being bought from local producer which is a lower price as compared to inorganic fertilizers. Other farm inputs costs like foliar fertilizer, insecticide, and mullosicide was found to be lower for MASIPAG due to the use of organic inputs such as FPJ, FAA, and FFJ used as insecticide and foliar fertilizer by the farmers. For mullosicide, farmers were using either rice hull or they control the water supply to control snails. Farmers have a net income of P116, 245.34 during dry season with a Return on income of 2.74 which means that, in every 1 peso of investment by the farmer they received 2.85 peso as a return. For wet season, a net income of P75, 684.76 with an ROI of 1.48 which indicates that in every peso invested by the farmer they received 1.48 peso as a return. 
TABLE VI: COST AND RETURN ANALYSIS RICE FARMING OF MASIPAG RICE FARMERS.

\begin{tabular}{lrr}
\hline \hline \multicolumn{1}{c}{ Particular } & \multicolumn{1}{c}{ Season } & \multicolumn{1}{c}{ Dry } \\
Yield & $3,096.82$ & \multicolumn{1}{c}{$2,477.46$} \\
Selling Price @ & $158,557.20$ & $126,845.76$ \\
Php80(milled) & & \\
& $\mathbf{1 5 8 , 5 5 7 . 2 0}$ & $\mathbf{1 2 6 , 8 4 5 . 7 6}$ \\
Gross Income & $2,034.38$ & $1,017.19$ \\
Seeds & $3,656.96$ & $3,291.27$ \\
Fertilizer & 591.93 & 532.74 \\
Pesticides & $\mathbf{6 , 2 8 3 . 2 7}$ & $\mathbf{4 , 8 4 1 . 2 0}$ \\
Farm Inputs & $5,745.14$ & $5,745.14$ \\
Land Preparation & 1248.18 & $10,289.93$ \\
Planting & 2402.78 & 2402.78 \\
Cultural Management & $6,708.77$ & $6,708.77$ \\
Harvesting & $\mathbf{1 6 , 1 0 4 . 8 7}$ & $\mathbf{2 5 , 1 4 6 . 6 2}$ \\
Farm Labor & $\mathbf{3 , 9 7 9 . 2 0}$ & $\mathbf{5 , 2 2 8 . 6 8}$ \\
Value Adding Cost & $\mathbf{1 5 , 9 4 4 . 5 2}$ & $\mathbf{1 5 , 9 4 4 . 5 2}$ \\
Other Cost & $\mathbf{4 2 , 3 1 1 . 8 6}$ & $\mathbf{5 1 , 1 6 1 . 0 2}$ \\
TOTAL COST & $116,245.34$ & $\mathbf{7 5 , 6 8 4 . 7 4}$ \\
Income/Hectare & & \\
Return on Income & $\mathbf{2 7 4 . 7 3 \%}$ & $\mathbf{1 4 7 . 9 3 \%}$ \\
above cost (\%) & & \\
\hline \hline
\end{tabular}

TECHNICAL EFFICIENCIES EFFECTS AND VARIANCE PARAMETERS OF STOCHASTIC FRONTIER MODEL OF MASIPAG FARMERS IN IN ISABELA, PHILIPPINES.

\section{A. Maximum Likelihood Estimates}

Table 7 reflects the Maximum Likelihood Estimates (MLE) of the stochastic frontier model. On MLE, seeds, fertilizer, were found to be highly significant at $1 \%$. Seeds with a coefficient of 0.20 and t-ratio of 1.73 means that as the farmer increases the volume of seeds in their production, farmer become more efficient, same through with the fertilizer with a coefficient of 0.23 and t-value of 1.74 which give greater efficiency to the farmers. Pre and post-harvest labor and capital were found to be significant at $5 \%$ level of significance. Pre and post-harvest labor with a coefficient of 0.64 and t-value of 5.16 which make the farmer more efficient as they increase the labor. Seeds, fertilizer and labor considers the law of diminishing return that as these variable increases technical efficiency also increases but at some point, technical efficiency also decreases if these variables were too much. The capital with a coefficient of 0.10 and $t$ - value of 2.78 indicating that that as farmer increases their investment for the production they become more efficient. This was due to the fact that availability of funds makes them more efficient as they can buy all the necessary inputs during their operations. This findings was the same with the studies being conducted by the different researchers. They found out that seeds, fertilizer, labor, were significant determinants on the technical efficiency of rice farmers [12]-[15]. Capital were also found significant variable for the technical efficiency of the farmer as stochastic frontier model were used in the researches [16]-[18].
TABLE VII: MAXIMUM LIKELIHOOD ESTIMATES (MLE) OF THE STOCHASTIC FRONTIER MODEL OF MASIPAG RICE FARMERS I IN ISABELA, PHILIPPINES.

\begin{tabular}{clcc}
\hline \hline Variable & Name of Variable & Coefficient & t-ratio \\
$\mathrm{X}_{0}$ & Constant & 3.99 & $4.38^{* *}$ \\
$\mathrm{X}_{1}$ & $\begin{array}{l}\text { Seeds (Kg/has) } \\
\text { Organic Fertilizer } \\
\text { (Kg/has) }\end{array}$ & 0.20 & $1.73^{* *}$ \\
$\mathrm{X}_{2}$ & $\begin{array}{l}\text { Pre and Post- } \\
\text { Pre Labor }\end{array}$ & 0.23 & $1.74^{* *}$ \\
$\mathrm{X}_{3}$ & $\begin{array}{l}\text { Harvest } \\
\text { (man-day/ha) }\end{array}$ & 0.64 & $5.16^{* *}$ \\
$\mathrm{X}_{4}$ & $\begin{array}{l}\text { Pre and Post-Harvest } \\
\text { Machine Services } \\
\text { (machine hours/ha) }\end{array}$ & 0.25 & $1.61^{\text {ns }}$ \\
$\mathrm{X}_{5}$ & $\begin{array}{l}\text { Amount } \begin{array}{l}\text { Pesticide (L/has) } \\
\text { Capital(Php/has) }\end{array} \\
\mathrm{X}_{6}\end{array}$ & 0.02 & $0.20^{\mathrm{ns}}$ \\
\hline \hline
\end{tabular}

\section{B. Technical Inefficiency Effects}

The technical inefficiency effects of MASIPAG farmers in Tumauini, Isabela is shown in Table 7. It was found that the age and farming system were highly significant at $5 \%$. Age with a coefficient of 0.08 and 2.53 indicating that as the age of farmer increases, farmers become inefficient because man cannot work harder as the age of the body increases. Farming system with a coefficient of 1.43 and t-value of 2.82 indicating that as the farmer uses mono-cropping system in farming it gives them more inefficiency.

Household size, educational attainment (elementary), number of years in farming type of soil, crop establishment were found to be significant at $5 \%$. Household size with a coefficient of 0.32 and $t-$ value of 2.29 implies that as the size of family of the farmer increases, farmer become more inefficient. There is a tendency that capital for the rice production may be utilize for the family needs instead of farming operations. An educational attainment (elementary) variable with coefficient of 1.16 and t-value of 1.66 indicates that as the farmer finished only their elementary studies, this gives them greater inefficiency. This may be the reason of some technical knowledge on farming requires higher level of thinking to understand the other matters on farming. Number of years on farming with -0.07 and $t$-value of -2.23 indicating that as the farmers spends longer time on farming it gives their greater efficiency. Holding other else constant, farmers get more efficient from experience by learning by doing of the farmers and the technology and knowledge that they received from trainings and seminars as one of the benefit of joining their organizations. Type of soil with a coefficient of -2.38 and tvalue of -2.60 making the farmer more efficient as they used the clay loam type of soil. Clay loam soil was suitable for the rice plant. Crop establishment with a coefficient of -1.31 and t-value of -1.79 conveys that as farmer uses the "waray" method of they become more efficient. This was because of the time that was being save as compared to other way of planting rice like straight line method. All other factors were found not significant.

The estimated sigma squared is 0.24 which indicates that it has a significant difference and the model is 
a good fit. The gamma parameter indicates whether all deviations from the model caused by random error or technical inefficiency. Sigma square was found to be highly significant indicating that rice production efficiency are not all $100 \%$ efficient. While gamma was also highly significant means that the deviation from the frontier were due to technical inefficiency.

TABLE VIII: TECHNICAL INEFFICIENCIES EFFECTS AND VARIANCE PARAMETERS OF STOCHASTIC FRONTIER MODEL OF MASIPAG FARMERS IN ISABELA, PHILIPPINES

\begin{tabular}{|c|c|c|c|}
\hline Parameter & Variable & Coefficient & t-ratio \\
\hline $\mathrm{d}_{0}$ & Constant & -0.32 & $-0.35^{\mathrm{ns}}$ \\
\hline $\mathrm{d}_{1}$ & Age & 0.08 & $2.53 * *$ \\
\hline $\mathrm{d}_{2}$ & Household Size & 0.32 & $2.29 * *$ \\
\hline $\mathrm{d}_{3}$ & Elementary level & -0.4 & $-0.69^{n s}$ \\
\hline $\mathrm{d}_{4}$ & $\begin{array}{l}\text { Elementary } \\
\text { graduate }\end{array}$ & 1.16 & $1.66^{*}$ \\
\hline $\mathrm{d}_{5}$ & $\begin{array}{l}\text { High school level } \\
\text { High school }\end{array}$ & -1.38 & $-1.59^{\mathrm{ns}}$ \\
\hline $\mathrm{d}_{6}$ & graduate & 0.48 & $0.82^{\mathrm{ns}}$ \\
\hline $\mathrm{d}_{7}$ & College level & -0.25 & $-0.33^{\mathrm{ns}}$ \\
\hline $\mathrm{d}_{8}$ & $\begin{array}{l}\text { College Graduate } \\
\text { No. of years in }\end{array}$ & 0.07 & $0.12^{\mathrm{ns}}$ \\
\hline $\mathrm{d}_{9}$ & $\begin{array}{l}\text { Farming } \\
\text { Land Tenancy }\end{array}$ & -0.07 & $-2.23 *$ \\
\hline $\mathrm{d}_{10}$ & $\begin{array}{l}\text { Status } \\
\text { No Trainings/ }\end{array}$ & -0.23 & $-0.41^{\mathrm{ns}}$ \\
\hline $\mathrm{d}_{11}$ & Seminar Attended & -0.13 & $-0.72^{\mathrm{ns}}$ \\
\hline $\mathrm{d}_{12}$ & $\begin{array}{l}\text { Type of Farm } \\
\text { Area of }\end{array}$ & -0.32 & $-0.35^{\mathrm{ns}}$ \\
\hline $\mathrm{d}_{13}$ & Farm(hectare) & -0.11 & $-0.48^{n s}$ \\
\hline $\mathrm{d}_{14}$ & Topography & 0.15 & $0.23^{\mathrm{ns}}$ \\
\hline $\mathrm{d}_{15}$ & $\begin{array}{l}\text { Type of soil } \\
\text { Number of times } \\
\text { of planting in a }\end{array}$ & -2.38 & $-2.60 * *$ \\
\hline $\mathrm{d}_{16}$ & year & -0.32 & $-0.35^{\mathrm{ns}}$ \\
\hline $\mathrm{d}_{17}$ & $\begin{array}{l}\text { Seed Selection } \\
\text { Seed germination }\end{array}$ & -0.32 & $-0.35^{\mathrm{ns}}$ \\
\hline $\mathrm{d}_{18}$ & treatment & -0.32 & $-0.35^{n s}$ \\
\hline $\mathrm{d}_{19}$ & $\begin{array}{l}\text { Land Preparation } \\
\text { Crop }\end{array}$ & -0.88 & $-1.32^{\mathrm{ns}}$ \\
\hline $\mathrm{d}_{20}$ & $\begin{array}{l}\text { Establishment } \\
\text { Nutrient }\end{array}$ & -1.31 & $-1.79 *$ \\
\hline $\mathrm{d}_{21}$ & $\begin{array}{l}\text { Management } \\
\text { Integrated nutrient }\end{array}$ & -0.62 & $-0.63^{n s}$ \\
\hline $\mathrm{d}_{22}$ & management & 0.2 & $0.46^{\mathrm{ns}}$ \\
\hline $\mathrm{d}_{23}$ & $\begin{array}{l}\text { Pest Management } \\
\text { Water }\end{array}$ & -0.32 & $-0.35^{\mathrm{ns}}$ \\
\hline $\mathrm{d}_{24}$ & Management & -0.32 & $-0.35^{\mathrm{ns}}$ \\
\hline $\mathrm{d}_{25}$ & Harvesting & -0.36 & $-0.43^{\mathrm{ns}}$ \\
\hline $\mathrm{d}_{26}$ & Farming System & 1.43 & $2.82 * *$ \\
\hline $\mathrm{O}^{2}$ & Sigma-Squared & 0.24 & $4.53 * *$ \\
\hline $\mathrm{Y}$ & Gamma & 0.75 & $12.28 * *$ \\
\hline
\end{tabular}

Stochastic frontier line

Figure 1 and 2 reflects the performance of the rice farmers on their production from dry and wet season during 2016. Majority of them obtained rice yield (y) below the stochastic frontier line $(\mathrm{y} / \mathrm{c})$ which suggest that technical inefficiencies performance in rice production. There were lesser proportions of farmers who have obtained with better technical efficiency. But it can be observed that during dry season farmers performed better as compared to wet season.

Relationship of actual and calculated yields and efficiency coefficients of MASIPAG rice farmers

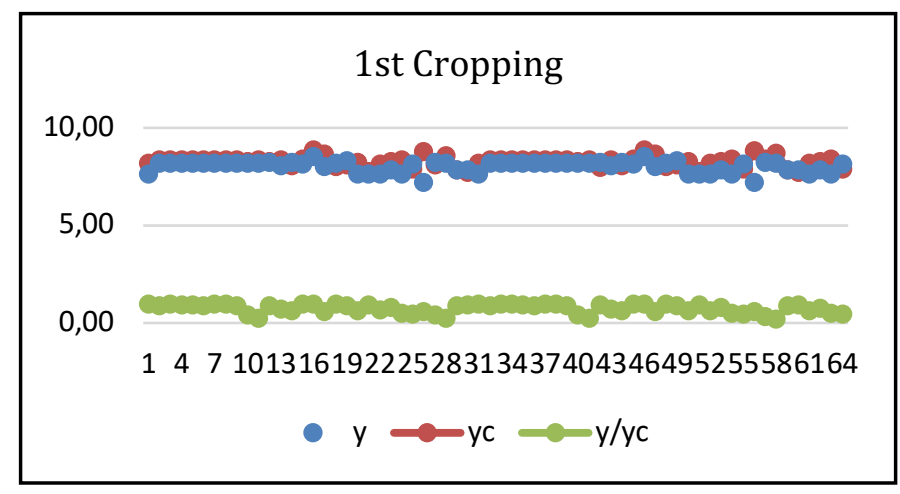

Figure 1. Stochastic frontline of MASIPAG Farmers on 1st Cropping

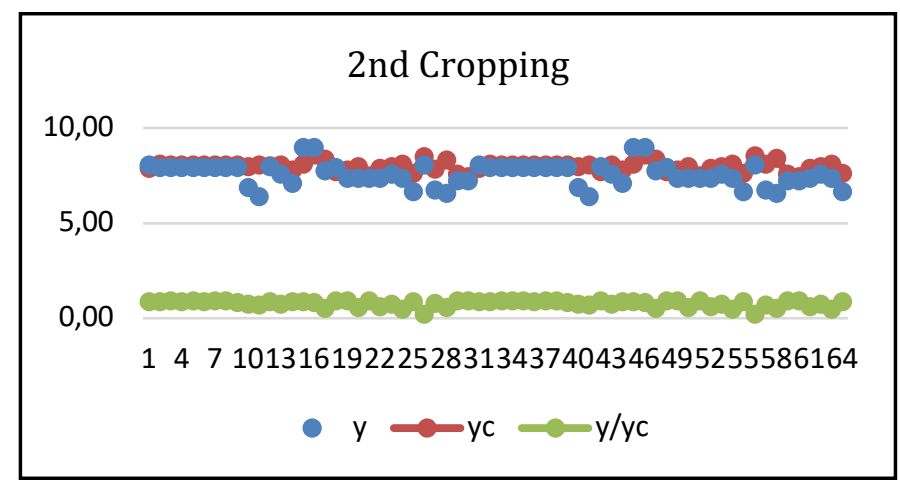

Figure 2. Stochastic frontline of MASIPAG Farmers on 2nd Cropping

\section{RECOMMENDATION}

Based from the findings, it is recommended to continue the practices on the operation of rice farming with the utilization and amount of seeds being used by the farmers. Using a natural and eco-friendly fertilizers is still advised to use since it increases their production and at the same time producing a safe and nutritious food. An exact amount of labor in their operation must be secured to maintain the efficiency of the farmers in utilizing manpower and time. The government may continue the support like financial assistance or available linkages for loans with a lower rate of interest. Participation of youth in agricultural production is encourage specifically children of farmers who are the next generations. Igniting the awareness and initiative through seminars symposium and conferences may be effective to persuade youth. The use of social media, 
might be a powerful tool to reach youth in the advocacy of involving younger generation in to the agricultural production. Extension programs for family planning is advised through the effort of the government that can minimize household sizes of the family as well as the population in the country. Providing farmers with both formal and informal education will be a useful investment and a good mechanism for improving efficiency in rice farming. Effort coming from the department of agriculture and other agencies in providing formal and informal education and trainings were also encourage. A diverse or integrated farming is recommended that can be practice by the farmers and can improve technical efficiency and increase on the income of the farmers.

\section{ACKNOWLEDGMENT}

The author would like to thank "Magsasaka at Siyentipiko para sa Pag-unlad ng Agrikultura" (MASIPAG) farmers who served as the respondents of the study and to the comments and suggestions of the anonymous reviewers.

\section{REFERENCES}

[1] The Manila Times (2013). https://www.manilatimes.net

[2] Mina, C. and Reyes, C. (2009). Incorporating Regional Rice Production Models in Rice Importation Simulation Model: A Stochastic Programming Approach. Philippine Institute for Development Studies, Surian sa mga Pag-aaral Pangkaunlaran ng Pilipinas 1-58.

[3] Inquirer.net (2019). https://newsinfo.inquirer.net

[4] http://masipag.org/about-masipag

[5] Berezow, A. (2016). Organic Farms Yield 20\% Fewer Crops than Conventional Farms. American Council on Science Health.

[6] Arida, I.A. (2009). Problems in rice farming: a Filipino farmers' perspective. Food and Agriculture Organization of the United Nations.

[7] Abdullah, M. et al. (2013). Problems Faced by Rice Growing Farmers and Their Behavior to the Government Policies: A Case from Pakistan.

[8] Caňete, D. and Temanel, B. (2017). Factors Influencing Productivity and Technical Efficiency of Rice Farmers in Isabela, Philippines. Journal of Advanced Agricultural Technologies Vol. 4, No. 2. 111 122.

[9] Rasyid, M.N. et al. (2016). Factors that Influence Rice Production and Technical Efficiency in the Context of an Integrated Crop Management Field School Program. American Journal of Applied Sciences, 13 (11): 1201-1204.

[10] Aigner, D., KnoxLovell C.A., and Schmidt P. (1977). Formulation and Estimation of Stochastic Frontier Production Functions. Journal of Econometrics 6: 21-37.

[11] Meeusen, W. and Broeck, J. (1977). Efficiency Estimation from Cobb-Douglas Production Functions with Composed Error. International Economic Review 18: 435-44

[12] Benabise, M.T. Dolojan, F.M. and Hernando, M.B. (2016). Factors influencing productivity and efficiency of rice farming in Quirino. Philippine E-Journal.

[13] Koirala, K., Mishra, A., and Mohanty, S. (2014). Determinants of Rice Productivity and Technical Efficiency in the Philippines. Selected Paper prepared for presentation at the Southern Agricultural Economics Association Annual Meeting, Dallas, pg. 1-16.

[14] Michler, J.D. and Shively, G. (2012). Tenure and Technical Efficiency among Philippine Rice Farmers. Poster prepared for presentation at the Agricultural \& Applied Economics Association's 2012 AAEA Annual Meeting, Seattle, Washington.

[15] Mariano, M., Fleming E., and Villano A. (2011). Technical Efficiency of Rice Farms in Different Agroclimatic Zones in the Philippines: an Application of a Stochastic Metafrontier Model. Article in Asian Economic Journal.
[16] Wakili, A.M. and Hassan, A. (2015). Technical Efficiency of Small Scale Rice Production in Adamawa State, Nigeria International Conference on Chemical, Food and Environment Engineering, Dubai UAE.

[17] Ezekiel, A.A. (2014). Technical Efficiency of Rice Farmers in Ilesa Agricultural Zone of Osun State British Journal of Business and Management Research Vol.1, No.1, pp.63-68.

[18] Enwerem, V.A. and Ohajianya, D.O. (2013). Farm Size and Technical Efficiency of Rice Farmers in Imo State, Nigeria Greener Journal of Agricultural Sciences ISSN: 2276-7770 Vol. 3 (2). 128-136.

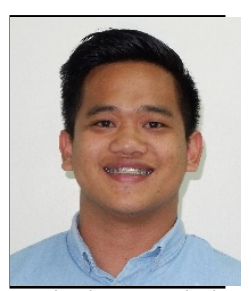

Jerald M. Velasco was born in Malibago, Echague, Isabela, Philippines on January 27, 1994. He finished his Master's Degree in Agribusiness Management at Nueva Vizcaya State University (NVSU), Bayombong, Nueva Vizcaya, Philippines.

Right after graduating in college (2014), he was hired as an Instructor in the Department of Agribusiness and Agricultural Economics, College of Agriculture, Isabela State University to teach Agribusiness and Agricultural Economics courses. As of the moment he is the Chairman of the Department. A Licensed Agriculturist and Professional Teacher recognized by Professional Regulation Commission (PRC) in the Philippines. The author is actively involved in the on-going research projects funded by the Department of Agriculture- Bureau of Agricultural research DA-BAR and Commission on Higher Education (CHED). He is also a member of various organizations such as: Philippine Agriculturist Association (PAA), Entrepreneurship Educator' $s$ Association (ENEDA), Council of Economics Educators (CECON), Crop Science Society of the Philippines (CSSP), Global Researchers' Association on Convergence for Excellence Inc. (GRACE), Asian Academic Association in Research and Management Inc. (AAARM), and Asian Intellect for Academic Organization and Development Inc. (AIAOD). 